Tjalling C. Koopmans Research Institute Tplligh Aoopman

Discussion Paper Series nr: 03-12

\title{
The Rise and Fall of Communal Liability in Ancient Law
}

Francesco Parisi

Giuseppe Dari Mattiacci 


\section{Tjalling C. Koopmans Research Institute Utrecht School of Economics Utrecht University}

Vredenburg 138

3511 BG Utrecht

The Netherlands

telephone (0031) 0302539800

fax (0031) 0302537373

website www.koopmansinstitute.uu.nl

The Tjalling C. Koopmans Institute is the research institute and research school of the Utrecht School of Economics.

It was founded in 2003, and named after Professor Tjalling C. Koopmans, the Dutch born Nobel Prize laureate in economics in 1975.

In the discussion papers series the Koopmans Institute publishes results of ongoing research for early dissemination of research results, and to enhance discussion with colleagues.

Please sent any remarks or questions on the Koopmans institute, or this series to P.vanDriel@econ.uu.nl

ontwerp voorblad: WR IK Utrecht

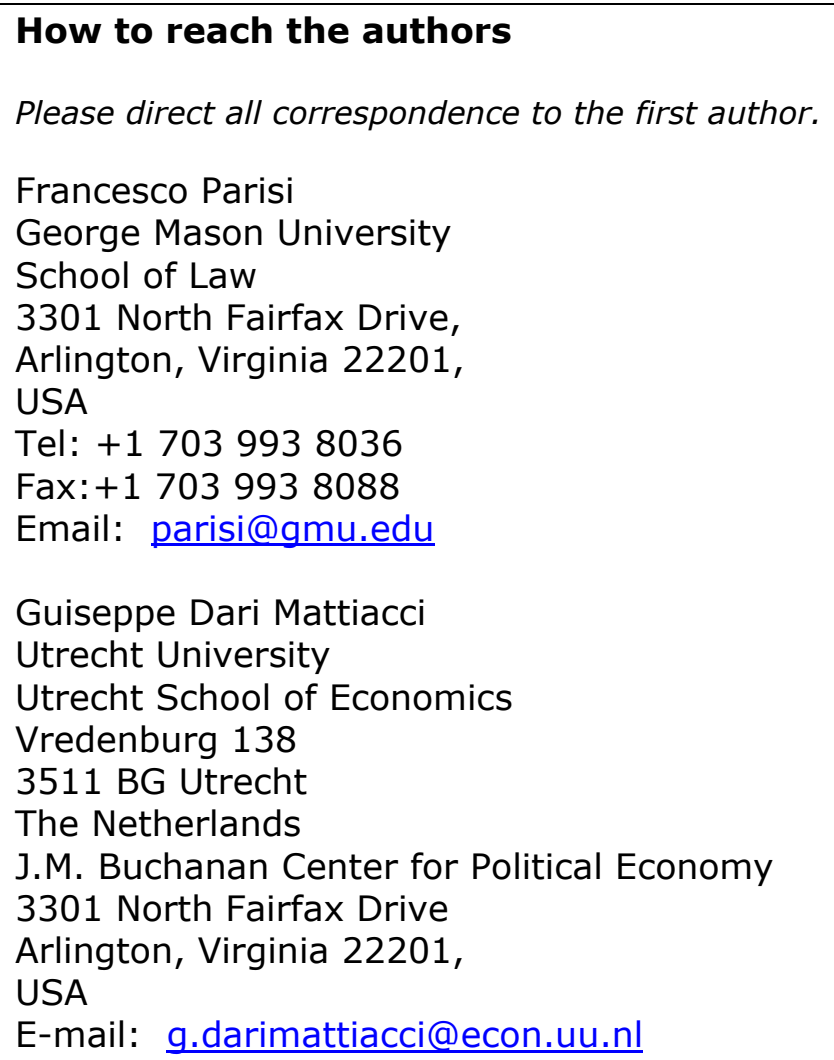


Utrecht School of Economics

Tjalling C. Koopmans Research Institute

Discussion Paper Series 03-12

\title{
The Rise and Fall of Communal Liability in Ancient Law
}

\author{
Francesco Parisi a \\ Guiseppe Dari Mattiacci bc \\ a George Mason University, School of Law \\ ${ }^{\mathrm{b}}$ Utrecht School of Economics \\ c J.M. Buchanan Center for Political Economy
}

September 2003

\begin{abstract}
In ancient societies, rules of communal responsibility permitted the imposition of retaliatory sanctions on a wrongdoer's clan. These rules followed the collective ownership structure of early communities. Over time, notions of personal responsibility emerged, terminating the transfer of responsibility from one member to the whole clan. This paper intends to provide an economic explanation for this transition.
\end{abstract}

Keywords: communal liability, tort, ancient law, primitive society, group liability.

JEL classification: C23 D31, J31, J60

"I the Lord thy God am a jealous God, visiting the iniquity of the fathers upon the children unto the third and fourth generation of them that hate me."

(Deuteronomy 5:9)

"The fathers shall not be put to death for the children, nor the children be put to death for the fathers, but every man shall be put to death for his own sin."

(II Kings 14:5-6)

\section{Acknowledgements}

We are indebted to Fernando Gomez, Antony Ogus, Göran Skogh and the participants in the Annual Meeting of the European Association of Law and Economics at Nancy 2 University for insightful suggestions. We would also like to thank Robert D. Cooter, Roger D. Congleton, Lewis Kornhauser, Janet Landa, Richard H. McAdams, Geoffrey P. Miller, Richard A. Posner, Charles K. Rowley, Michael Trebilcock, and Thomas Ulen, as well as the participants at the Yeshiva University Workshop in Law \& Economics for valuable comments on an earlier draft of this paper first circulated under the title of "Liability without Fault and Communal Liability in Ancient Law". 


\section{Introduction}

In this paper, we consider the transition from communal to individual responsibility under a collective ownership regime. We explain the decline of communal responsibility as an effect of the exacerbation of common pool and free rider problems with an increase in group size and wealth. The conclusion evaluates this transition in light of the competing functions of liability rules in early societies.

In a study of retribution and related concepts of punishment, Posner (1980) considered the interesting case of communal liability in the early law of wrongs, discussing the notion of "pollution" according to which the wrongdoer's bad act visits retribution on neighbors and descendants. According to Posner, this concept, seemingly unsupportable in economic terms, makes the retributive punishment function more effective by helping to ensure that certain crimes are more likely to be detected and punished. Since people believed that the gods could see and punish their crimes, they were likely to be deterred even when detection and punishment would be unlikely from society. ${ }^{1}$ Along Posner's lines, we suggest that economic tools can help explain other interesting and seemingly odd features of the ancient law of wrongs.

Communal liability implied that a clan was collectively responsible for damage caused by any of its members. ${ }^{2}$ Communal liability can be seen as a byproduct of the economic structure of early societies. The family-based economy of the time, if seen through modern eyes, left very little room for alternative models of individual responsibility. Each member contributed to the collective welfare of the clan, but inasmuch the clan was to enjoy the gains procured by the individual member, it was to suffer - and pay - for the losses that he occasioned. Given the communal nature of early responsibility, talionic sanctions were rarely imposed when the wrong was committed against a member of the same clan. Likewise, in later times, when talionic penalties were replaced by blood-money payments, no money transfers would take place within the group for compensating wrongful losses. ${ }^{3}$ This fact is also consistent with the goal of

${ }^{1}$ Posner (1980 and 1981). Retribution, retaliation and even pollution are economically rational concepts of punishment in the historical circumstances in which they are primarily found. In Posner's analysis the logic hinges on negative altruism $C$ that people can obtain utility from inflicting costs on people who have injured them. It also suggests that ethical concepts change over time with the change in cost of access to information.

${ }^{2}$ Daube (1947b), at 154.

${ }^{3}$ Although a pecuniary sanction paid by a clan to itself would have been meaningless, the personal punishment of 
appeasement. Besides internalizing external costs, liability regimes also functioned to prevent the animosity that might follow a wrongful act from escalating into an uncontrolled wave of retaliatory violence. Because of communal responsibility, whenever the wrong was committed against a member of the same clan, there was no reason to fear any controversy.

When the wrongdoer belongs to the same group as the victim, it is highly improbable that it will arouse any form of retaliatory punishment. Even when the wrongful behavior appears to justify resentment on the part of other clan members, "there is no remedy, and the tribe simply does nothing save where the offence is so serious as to break all bounds. The situation is analogous to that in which one breaks or damages his own property by accident; it is regrettable, but there is no remedy but an imprecation." ${ }^{4}$

Anthropologists have considered the origins of the desire for retaliation, and explored the sociological foundations of the clan's unity in avenging the harm suffered by only one of its members, concluding that the early clan served as a mutual protection association. ${ }^{5}$ With the help of a simple model, we consider the rise and gradual fall of communal liability as an adaptation of liability rules to the changing needs of early societies. Section 2 portrays the historical context and describes communal responsibility as a no-fault regime. Section 3 studies the effects of communal ownership and communal liability on private incentives to reduce crime and contribute to the group's security. It is shown that, given the presence of a common pool problem, individual incentives are diluted both by an increase in the group size and by an increase in the group wealth. We suggest that the exacerbation of the common pool and free riding problems associated with a communal responsibility regime fostered the move towards individual responsibility as soon as groups grew bigger and wealthier. Section 4 concludes discussing the fall of primitive communal liability regimes and the gradual replacement of public enforcement to private vindication.

\footnotetext{
the offender within the same group would have been a conceivable and viable option. Faris (1915) observes that there is abundant reason for questioning whether anyone inside the primitive group was ever punished, at least by those within his tribe. In light of the available data, Faris' conclusion should be endorsed. The head of a clan would be very unlikely to inflict punishment on members of his own clan, since any such punishment would result in a reduction of his own patrimony.

${ }^{4}$ Faris (1915), at 153.

${ }^{5}$ The wrong was always felt to be committed against the clan to which the victim belonged. It was, therefore, the clan which had to be satisfied with punishment or compensation. See Hoebel (1954), with many references to primitive civilizations. For the distinctions between tribes and clans as centers of collective interests, see Powell (1915).
} 


\section{Liability without Fault and Communal Responsibility in Ancient Society}

A characterizing feature of ancient legal systems may be found in their religious roots. ${ }^{6}$ In many systems of archaic law, a wrongful action was primarily a $\sin ,{ }^{7}$ and punishment satisfied the religious need for expiation. ${ }^{8}$ Despite the religious origin of these rules, the concept of responsibility was initially logically independent of notions of individual blameworthiness. Punishment was imposed on the wrongdoer's clan merely because a divine rule had been infringed. ${ }^{9}$ The Old Testament provides many illustrations of the original irrelevance of subjective factors in the assessment of responsibility. A wrong could have been committed without intent or fault, yet the wrongdoer was subject to punishment. ${ }^{10}$ Sanctions were thus independent of the ascertainment of the wrongdoer's state of mind at the time of the accident. The real gravamen of a charge against the aggressor was the harm itself, ${ }^{11}$ and what mattered was the fact that an injury had occurred because of somebody's act. The subjective circumstances of the accident remained a matter of only secondary importance. In most systems of archaic law, the whole distinction between fault and accident was still quite unclear. Religious beliefs in witchcraft and evil possession of human beings justified the imposition of punishment on individuals and families that were free of any blame. The idea that spirits could guide human action rendered any possible theoretical distinction between intent and accident hardly relevant. ${ }^{12}$ If the act was intentional or negligent, punishment served to deter future wrongdoing; if it was committed

\footnotetext{
${ }^{6}$ In this setting, scholars of ancient civilizations have stressed the role of religion as a source of law. The infliction of punishment for committed wrongs is often vested with religious obligatory force. Punishment is demanded by the conscience of society, and its imposition in the absence of subjective blame of the wrongdoer is explained as a necessary sacrifice to an offended god, whose rage might otherwise descend on the entire community. Most recently, Strachan-Davinson (1912), at 1, observes that the concept of punishment as religious obligation, though overridden by considerations more appropriate to civilized man, has left clear traces in later Roman law.

${ }^{7}$ Tunc (1974), Maine (1883), at 5, writes: “There is no system of recorded law, literally from China to Peru, which, when it first emerges into notice, is not seen to be entangled with religious ritual and observance." For further analysis, see Maine (1861), at 371, who observes that the law administered at Athens by the Senate of Areopagus, for example, probably entailed "penal consequences on certain classes of acts and on certain classes of omissions, as being violations of divine prescriptions and commands".

${ }^{8}$ See L'Hour (1963).

${ }^{9}$ For the gradual development of the concept of culpability as a necessary element of responsibility in Hebrew law, see Gaudemet (2002) and Daube (1947a), at 107. See also De Coulanges (1915).

${ }^{10}$ See, for example, Leviticus 5:17-18.

${ }^{11}$ Asylum, however, was a route open to persons who had killed involuntarily (Exodus 21:12-14; Deuteronomy 19:4-6). Refuge for unintentional homicide can be viewed as a tool to avoid the infliction of talionic punishment. But this does not imply, as a general rule, the exclusion of liability for unintentional wrongs. See Hobhouse (1915). For a discussion of unintentional homicide in Islamic law, see Anderson (1951) and Diamond (1971).

${ }^{12}$ Hobhouse (1915), at 140-141, observes: "My son, or brother, or cousin, or clansman is killed; that is enough for me: I [i.e., my family] must have some satisfaction out of the man who did it [i.e., out of his family]." See also Hoebel (1954).
} 
unintentionally, it was still necessary to purify the possessed soul. In this way, punishment served as a sacrifice to the offended god, as illustrated by the religious belief according to which the evil element must be put away if the nation is to prevent guilt and punishment from being inflicted on the entire community. ${ }^{13}$

Ancient societies had different ways of dealing with wrongs, depending on whether the harm was occasioned by a member of the clan or by an outsider. If the harm was caused by a member, the loss was treated as a misfortune. Where the circumstances indicated that the harm was not merely accidental, the chief was likely to punish the tortfeasor, although physical retaliation was rarely implemented to avoid duplicating the loss to the group. The situation was quite different in the case of harm occasioned by an outsider. In this case, retaliatory rules specified the measure of acceptable retaliation to reestablish the equilibrium between clans.

The difficulty of proving the subjective elements should be counted as an additional reason for the avoidance of subjective criteria of liability in ancient laws. In Genesis, Adam and Eve failed the test of obedience and blamed each other to avoid personal responsibility. ${ }^{14}$ Adam, in a final attempt to justify himself, says: "The woman whom thou gavest to be with me, she gave me of the tree, and I did eat. ${ }^{\prime 15}$ When the Lord turns to Eve, asking what she has done, she justifies herself by shifting the blame onto the serpent: "The serpent beguiled me, and I did eat. ${ }^{16}$ The lack of any legal relevance in the notions of fault and imputability is to be explained by the difficulty of proving ${ }^{17}$ the subjective beliefs of parties involved in wrongful activity, ${ }^{18}$ and the likely exacerbation of inter-clan tensions brought about by a trial involving controversial evidence. Ancient liability systems were mostly concerned with the preservation of inter-group peace. In their attempts to place the blame on one another, anger - as opposed to satisfaction - was likely to arise in those who perceived themselves as victims of another's mischief. At this early stage of legal development, the use of fault-based liability would have undermined this appeasement goal.

\footnotetext{
${ }^{13}$ See Strachan-Davinson (1912) and, more profusely, in Chapter 1 on "Religion as a Source of Law."

${ }^{14}$ David Daube, in his lecture of November 17, 1988, at the University of California at Berkeley.

${ }^{15}$ Genesis 3:12.

${ }^{16}$ Genesis 3:13.

${ }^{17}$ For a survey of situations of stateless societies coping with wrongdoing and with the difficulties of proof in assessing responsibility, see Stein (1984).

${ }^{18}$ Daube (1947a).
} 


\subsection{Communal Ownership and Communal Responsibility}

The absolute nature of early tort law was originally coupled with notions of communal responsibility. In the ancient world, a clan was collectively responsible for damage caused by any of its members even if the damage was caused involuntarily. A paradigmatic example of communal responsibility is found in the Bible, according to which mankind suffers for the sins of Adam and Eve, ${ }^{19}$ and collective guilt continues to be passed on from generation to generation. ${ }^{20}$

The collective responsibility of the whole clan or family for the sins of one of its members continued to permeate the law of early societies. ${ }^{21}$ At a later stage, as an effect of the ethical revolution brought about by the later prophets, Jewish law developed a different theoretical ground for collective responsibility: blame was placed specifically on the wrongdoer, but sanctions could still affect the other members of the wrongdoer's community. ${ }^{22}$ An ancient rule stated that "a man who causes the death of another man's child is to lose his own." ${ }^{\prime 23}$ The Code of Hammurabi ${ }^{24}$ contains a similar rule, stating that if a man strikes a woman with child and she dies, his daughter shall be put to death. ${ }^{25}$

When talionic penalties are replaced by blood-money payments, communal liability remains under the form of communal pecuniary liability. ${ }^{26}$ The clan is collectively responsible for the blood-money owed by one of its members to the victim belonging to another clan. By the same logic, the clan is the collective recipient of blood-money due to any of its members. This rule applies to blood money as much as it applies to other non-delictual obligations. ${ }^{27}$ The communal

${ }^{19}$ Genesis 3.

${ }^{20}$ Exodus 20:5-6; Deuteronomy 5:9-10.

${ }^{21}$ The uniformity of rules among these ancient societies should not be surprising if we keep in mind that the Hebrew people had been subjected to both Egyptian and Babylonian control at different times in history. The law of ancient Israel was put into its definitive form during the Babylonian Exile and thus reveals the influence of both Egyptian principles and the more explicit precepts and of the Code of Hammurabi.

22 The collective responsibility of early laws permeates the systems even in later times when literal retaliation was replaced by pecuniary sanctions. Hobhouse (1915), at 140.

${ }^{23}$ Daube (1947b), at 169.

${ }^{24}$ Code of Hammurabi, Par. 210.

${ }^{25}$ These rules are definitely based on individual responsibility: only he who has committed the wrong is to be blamed. For an illustration of the difficulties of conceiving a notion of individual blame in a system of communal responsibility, see Daube (1947b), at 169.

${ }^{26}$ Legal historians generally identify four phases in the historical evolution from a system of retaliation to one based on victim's compensation. The four phases are commonly identified with reference to their most salient feature, namely: (1) the original absence of generally agreed-upon rules regarding the punishment of wrongs ("discretionary retaliation"); (2) the gradual emergence and articulation of a rule of proportional retaliation ("lex talionis" or "regulated retaliation"); (3) the commodification of the punitive entitlement, enabling the wrongdoer to buy out the victim's retaliatory right with pecuniary compensation ("blood-money"); and (4) the gradual replacement of lex talionis and blood-money with a system of fixed pecuniary penalties ("fixed penalties"). Parisi (2001).

${ }^{27}$ For further elaboration on this logic of communal responsibility in early legal systems, see Hobhouse (1915), at 
nature of early liability should not be surprising. In a regime of communal property, where the chief of the family holds property for the use of the other family members, any claim by a victim of wrongdoing occasioned by a member of the group is brought against the head of the family, since he is the only individual that can dispose of property for the purpose of compensation or restitution to the victim. $^{28}$

The absence of any intentional or subjective requirement, combined with the communal nature of responsibility, ${ }^{29}$ fulfilled the main societal needs of the time. ${ }^{30}$ These early rules achieved a peculiar balance between the prevention of crimes and the prevention of feuds arising from disputes among clans. ${ }^{31}$

\subsection{Communal Liability, Blood-Vengeance and the Administration of Justice}

Norms of communal responsibility are related to the regime of communal ownership of the early human communities. Any wrong suffered by a member of the group was perceived as a loss for the group as a whole. This communal loss called for a communal reaction of the victim's group against the tortfeasor's group. The ancient rules concerning the administration of justice provide quite interesting evidence of this course of events.

Unlike the customs followed prior to the lex talionis, the rules of the time of the lex talionis tend to specify with great precision who was entitled to impose the talionic punishment in a regime of regulated retaliation. For example, several rules of the lex talionis period designate an avenger of blood, who should carry out the talionic vindication on behalf of the victim.

In the biblical text, the appropriate passages to consider are Genesis 4:15, which describes the administration of justice prior to the lex talionis, and

139.

${ }^{28}$ Stein (1999).

${ }^{29}$ On the law of wrongs of the Hittites, see Gaudemet (2002) who observes that the principle of individualization of the sanction was predominant in the laws of the Hittites; however, some cases of familiar and communal responsibility still existed in that legal system, where, only exceptionally, goals of vengeance permeated the law. The author observes how the talion and corporal punishments were gradually substituted with pecuniary penalties that served to indemnify the victim rather than to castigate the offender.

${ }^{30}$ The attachment of liability to the owner of the thing, animal or slave remains throughout Roman law. An action followed the thing or being, regardless of its owner. Holmes (1881), at 11-13, discusses the ownership-based notion of liability, observing that in Roman law, if a paterfamilias committed a tort and he was subsequently adopted or reduced to slavery, a noxal action lay against his master in place of the direct one against him as the wrongdoer. This point is discussed later, with reference to Gaius, Institutiones, 4.77 and Justinian, Institutiones, 4.8.5.

${ }^{31}$ Williams (1951), at 138. See also Holmes (1881), at 6, on the early forms of liability and on the role of vengeance in early legal procedure. The aim of appeasement has long been associated with the tort system. In the $17^{\text {th }}$ century, however, Grotius (1625) saw the law of wrongs as a means of preventing squabbles among families and individuals. 
Deuteronomy 13:9, which describes the reformed rule of the lex talionis period. In Genesis the blood avenger is not a definite person. The vindication of an innocent victim is generally carried out by the victim's clan. As pointed out by the rabbinic interpretations, under the older tradition, any member of the tribe could carry out the retaliation. ${ }^{32}$ The action, however, was ordinarily orchestrated by the chief of the clan, who, acting as a residual claimant, had an interest in minimizing the external losses to his group.

According to this historical reconstruction, ordinary members of the clan were often forced to join the retaliatory expedition by the chief. The avengers of blood risked their own lives for the vindication of the group as a whole. These constituent bodies resemble a feudal-like organization, where the chief secures the aid of his people in carrying out the gloomy task of retaliation, in exchange for a reciprocal grant of protection against external aggression. In any society, there would be several of these constituent bodies. Yet, there is no sufficient development of comity among these groups to establish a more moderate settlement process.

Under the later rule of Deuteronomy, we find a more detailed specification of the procedure for the talionic punishment. In two distinct passages we read that "thou shalt surely kill him; thine hand shall be first upon him to put him to death, and afterwards the hand of all the people, ${ }^{\prime \prime 3}$ and again that "the hands of the witnesses shall be first upon him to put him to death [...] So thou shalt put the evil away from among you. ${ }^{\prime 34}$ These passages indicate that the victim and the witnesses are the first ones to vindicate the wrongdoing. Only later during the process may the other members of the community join the specified avengers of blood in the execution.

The diffuse punitive entitlement of the earlier customs described in Genesis rendered the administration of justice rather uncertain and unrestrained. ${ }^{35}$ As pointed out by Parisi (1997 and 2001), the change brought about by the rules of Deuteronomy reduced the risk of coordination errors, avoiding the possibility of multiple reprisals for the same wrong as well as the likelihood of leaving some wrongs unpunished.

Under the regime of Deuteronomy, the institution of Go'el, the nearest of blood, evolves. In the absence of a central law-enforcement system, the closest family member of the victim had the right - and more importantly, the duty - to

\footnotetext{
${ }^{32}$ See, Sulzberger (1915), at 1 and 116.

${ }^{33}$ Deuteronomy 13:9.

${ }^{34}$ Deuteronomy 17:7.

${ }^{35}$ Blau (1916), at 5.
} 
carry out retaliation. Failure to carry out such a gloomy task was considered disgraceful. This further assured the consistent punishment of wrongdoers.

In several other systems of ancient law, punishment was likewise carried out by the victim himself or by a member of his extended family. This retaliatory practice acknowledged and gratified each individual's personal need for revenge. Similar to the Biblical tradition, Babylonian rules left the punishing of crimes (including intentional killing) to the initiative of private parties. Although the Hammurabi Code ${ }^{36}$ provisions do not define the general domain of private law enforcement, many provisions expressly authorize the family of the victim to impose punishment on the offender, outside any official judicature. ${ }^{37}$ It is usually believed that during the time in which the state did not yet exercise its modern enforcement functions, minor social entities, such as families, guilds and clans had general authority over the punishing of wrongs. In punishing wrongs, they protected the safety of their members and vindicated the wrong suffered by members by the acts of those outside the group. ${ }^{38}$

Occasionally, these early laws did not formally indicate the person who would enforce the prescribed punishment. In such cases, philologists have deduced with a high degree of certainty that when the passive verb was used (e.g., "he shall be put to death") a public officer would carry out the execution. Conversely, the active form (e.g., "they shall kill him") implied that the injured party, or his clan, would carry out the talionic sanction. ${ }^{39}$

The involvement of an official executioner in early times did not yet amount to a centralization of criminal justice, but rather, signified that a wrongful act had directly harmed the public interest. Punishment carried out by an official executioner was viewed as the king's personal vindication against the transgressor of the social order. ${ }^{40}$ These cases confirm, rather than contradict, the private origin of criminal punishment.

As the law developed, the restrictions regulating vengeance were extended.

${ }^{36}$ It is generally believed that there is no direct derivation of the Biblical rules from the earlier Babylonian code. Rather, both codifications seem to have formalized preexisting practices of retaliation of common Semitic origin. See Mueller (1904), at 241.

${ }^{37}$ Par. 127 of the Code of Hammurabi expressly authorizes the family of an affronted high-priestess or married woman to personally impose punishment on the offender, outside any official judicature: "If a man has caused a finger to be pointed at a high-priestess or a married lady and has then not proved (what he has said), they shall flog that man before the judges and shave half his head."

${ }^{38}$ Sulzberger (1915), at 6-13. in Par. 108.

${ }^{39}$ An example of the passive form can be found in Par. 109 of the Code of Hammurabi, while the active form is used

${ }^{40}$ Driver and Miles (1952), at 498, observe that the official executioner was appointed by the king or governor. In light of the practical nature of early legal systems, a logical interpretation of the sources supports the conclusion that the vindication is the king's personal retaliation. For further analysis of the evolution of dispute settlements, see Stein (1984), at 1-24. 
The injured party, who was originally allowed to carry out the execution himself, later was only allowed to do so under the supervision of authority, and eventually was only permitted to attend the execution. A similar transition is observed in ancient Greece. In the fifth century BCE (year 403, circa), the Greek orator Lysias refers to the episode of Eratosthenes, who was put to death on the spot by the aggrieved husband in the presence of his friends. ${ }^{41}$ Later in the same tradition, as the Greek orator Demosthenes tells us, the state carried out the execution with the avenger of blood only entitled to watch. ${ }^{42}$ But, throughout these early legal systems, the evolution of a judicial procedure regulated, but did not yet supplant, the victim's right to talionic justice. ${ }^{43}$

\subsection{Talionic Justice and Communal Responsibility}

Another feature of the ancient law of wrongs illustrates the necessity of a system of communal responsibility. Several ancient rules of talionic justice required that the penalty be imposed with uncompromising symmetry, replicating the harm suffered by the victim and his or her family. In a regime of communal responsibility, this mirror-image symmetry produced some paradoxical rules. The laws of the ancient near east give five clear examples of this peculiar dispensation of punishment. For example, in the Assyrian Laws of the eleventh century BCE, the wife of a rapist must be given over to the victim's family to be raped. ${ }^{44}$ And again, if an ox killed a child, the Code of Hammurabi required the death of the owner's child. In the same Babylonian code we read that if a man strikes a woman and then she dies, they shall put his daughter to death. ${ }^{45}$ And again, for builders whose structures fall down, the Code of Hammurabi prescribes that if the owner of the building dies, the builder shall be put to death. ${ }^{46}$ If the owner's son is killed,

\footnotetext{
${ }^{41}$ Lysias, Orationes, 1.25-7; cp. 32

${ }^{42}$ See the fourth century BCE narrative of the Greek orator Demosthenes, Orationes 23.69.

${ }^{43}$ In the early administration of justice, talionic rules applied only to inter-clan wrongs. The harm occasioned by those within the clan was generally not subjected to talionic penalties. The harm occasioned by members of another clan was to be repaid in kind. The mitigated punishment of the insiders was necessary to avoid the duplication of losses within the clan, unless the wrongdoer was likely to further imperil the community. Sulzberger (1915), at 3, observes that under the regime of the lex talionis individual retaliation ceases to be unrestrained and that a member of the family cannot slay a fellow member of his family, as suggested by the author's interpretation of Exodus 4:24-26. The co-existence of two distinct regimes (inter-clan versus intra-clan) tends, according to Sulzberger, to undermine the lex talionis, given the changing and expanding conception of the boundaries of the group. This may indeed provide an additional explanation for the gradual corrosion of the literal interpretation of the lex talionis in the Biblical tradition.

${ }^{44}$ Paragraph 55 of the Middle Assyrian Laws. See Roth (1995), at 174-175.

${ }^{45}$ Paragraph 209 and 210 of the Code of Hammurabi.

${ }^{46}$ Paragraph 229 of the Code of Hammurabi.
} 
the builder's son shall be put to death. ${ }^{47}$

Similarly, in the Biblical tradition several passages, most of which are of mere symbolic value, stress the importance of replicating the punishment with symmetrical identity to the circumstances of the offence. Thus, for example, in Exodus Moses is sent to warn Pharaoh to let Israel, God's first-born, go, or else Pharaoh's first-born would be killed. ${ }^{48}$ Likewise, in the second book of Samuel, we find the narrative of a person who has killed his childless brother. In order to simulate the gravity of the harm occasioned (death of a person who will have no descendants), the avenger of blood threatens to kill the murderer and his son. ${ }^{49}$

Generally, the later Biblical sources grant the victim's family a right to inflict harm on the wrongdoer by means of proportional retaliation but such talionic penalty is directed towards the specific wrongdoer rather than the wrongdoer's family as a whole. $^{50}$

\section{Individual Incentives and Common Pool Problems in Communal Liability}

In this section, we study the incentive effects of a regime of communal liability. With their own behavior, individual members of a clan affect the wellbeing of the group by engaging in wrongful behavior against members of other groups, hence triggering retaliatory sanctions and blood-money payments against the clan, and by cooperating with other members of the clan in the production of common wealth and security.

\subsection{A Model of Communal Liability}

Consider a society composed of $\mathrm{N}$ individuals with identical utility functions,

$$
U=u(Y, S, C) \text {. }
$$

\footnotetext{
${ }^{47}$ Paragraph 230 of the Code of Hammurabi.

${ }^{48}$ Exodus 18:11. Note, however, that other Biblical rules combat this kind of transmission of penalty to other members of the wrongdoer's family. See Exodus 21:31

${ }^{49}$ II Samuel 14:1-7

${ }^{50}$ The transition from communal to individual responsibility is irreversibly achieved in the $6^{\text {th }}$ century BCE, through the work of prophet Ezekiel, as already anticipated in a well known passage of Deuteronomy 24:16, affirming the principle of individual responsibility: "The fathers shall not be put to death for the children, neither shall the children be put to death for the fathers." Further analysis of this interesting transition can be found in Parisi (1992 and 1997).
} 
Here, $\mathrm{Y}$ denotes a generic bundle of consumption goods, $\mathrm{S}$ denotes the effort expended by each individual in securing the group's wealth, and $C$ denotes criminal activity against members of other clans. The utility function is assumed to be increasing in $\mathrm{Y}$ and $\mathrm{C}$ and decreasing in $\mathrm{S}$, differentiable and well-behaved, with the usual characteristics

$$
\mathrm{U}_{\mathrm{Y}}, \mathrm{U}_{\mathrm{C}}>0 ; \mathrm{U}_{\mathrm{S}}, \mathrm{U}_{\mathrm{YY}}, \mathrm{U}_{\mathrm{SS}}, \mathrm{U}_{\mathrm{CC}}<0 ; \quad \mathrm{U}_{\mathrm{YS}}, \mathrm{U}_{\mathrm{YC}}=0
$$

The clan has a collective endowment of resources $W$. Individual members of the clan receive an equal share of the common wealth, $\mathrm{W} / \mathrm{N}$. Thus,

$$
\mathrm{Y}=\mathrm{W} / \mathrm{N} \text {. }
$$

The clan's wealth W is composed of initial wealth K plus wealth produced by the individual according to his effort $S^{51}$ minus the cost of retaliation by other groups, which is assumed to be a blood-money equivalent of the talionic reaction triggered by crime $\mathrm{C}^{52}$ Thus,

$$
W=K+W(S)-C \quad W_{S}>0 ; W_{S S}<0 .
$$

Substituting (3) and (4) into (1), the utility function can thus be rewritten as

$$
U=u\left(N^{-1}[K+w(S)-C], S, C\right)
$$

Let us assume that $\mathrm{U}$ is a strictly concave function of $\mathrm{S}$ and $\mathrm{C}$. We can now consider the first order conditions of our objective function to study the equilibrium levels of crime and security in a regime of communal responsibility. The first order conditions to be simultaneously satisfied for individual optimization with respect to $C$ and $S$ yield

$$
\mathrm{F} \equiv \partial \mathrm{U} / \partial \mathrm{C}=-\mathrm{N}^{-1} \mathrm{U}_{\mathrm{Y}}+\mathrm{U}_{\mathrm{C}}=0
$$

\footnotetext{
${ }^{51}$ The individual effort, $\mathrm{S}$, includes the input of the group member in productive activities, as well efforts directed towards the internal monitoring and prevention of criminal activities, defense, and retaliatory efforts.

${ }^{52}$ Under the regime of communal retaliatory justice under consideration, an increase in the group's wealth or strenght had no impact on the ability of the group to carry out retaliation or escape retaliation imposed by others. When justice required the imposition of punishment on a strong offender by a weak victim, support would be provided by the community at large to ensure the imposition of proper retaliatory penalties. For this reason we assume that talionic penalties would be imposed independently of the relative strenght of the parties.
} 
and

$$
\mathrm{H} \equiv \partial \mathrm{U} / \partial \mathrm{S}=\mathrm{N}^{-1} \mathrm{U}_{\mathrm{Y}} \mathrm{W}_{\mathrm{S}}+\mathrm{U}_{\mathrm{S}}=0
$$

Let $\mathrm{C}^{*}$ and $\mathrm{S}^{*}$ be the values of crime and security that satisfy the first order conditions and let them be positive.

\subsection{The Effects of Clan Size on Security and Crime}

We can now study how the levels of security and crime vary if the group size changes. To do so, let us first sign $F_{C}$ and $F_{N}$ :

$$
F_{C}=N^{-2} U_{Y Y}+U_{C C}<0,
$$

and

$$
F_{N}=N^{-2} U_{Y}-N^{-3} U_{Y Y} W>0 .
$$

This allows us to apply the Implicit Function Theorem to study how $C^{*}$ varies with the group size $\mathrm{N}$. We can determine that

$$
\partial \mathrm{C}^{*} / \partial \mathrm{N}=-\mathrm{F}_{\mathrm{N}} / \mathrm{F}_{\mathrm{C}}>0
$$

This indicates that the privately optimal value of $C^{*}$ increases with clan size. The result derives from the fact that the individual member of the clan gets the direct benefit $C$ from the commission of a wrong on third parties, while suffering only $1 / \mathrm{N}$ of the consequential loss from retaliation against the clan's collective wealth. This share of individual cost decreases with $\mathrm{N}$ (i.e., an increasingly smaller share of $\mathrm{C}$ is internalized by the individual agent), and thus the optimizing level of $C^{*}$ is shown to grow with group size. ${ }^{53}$

A similar analysis can be conducted with respect to optimal expenditures on security by the members of a large clan. Let us first sign $\mathrm{H}_{\mathrm{S}}$ and $\mathrm{H}_{\mathrm{N}}$ :

${ }^{53}$ This result provides interesting insights concerning the endogenous nature of clan size and its relevance to the incentives of clan members. The fundamental economic intuition can be nicely derived from the economic theory of teams. The model and underlying intuition of this paper is precisely what the economic theory of teams would generate, and it can offer many interesting analogs from modern situations. 


$$
H_{S}=N^{-2} U_{Y Y}\left(W_{S}\right)^{2}+N^{-1} U_{Y} W_{S S}+U_{S S}<0,
$$

and

$$
H_{N}=-N^{-2} U_{Y} W_{S}+N^{-3} U_{Y Y} W_{S} W<0 .
$$

As for the former problem we can study how $S^{*}$ varies with the group size $\mathrm{N}$. We can determine that

$$
\partial S^{*} / \partial \mathrm{N}=-\mathrm{H}_{\mathrm{N}} / \mathrm{H}_{\mathrm{S}}<0 .
$$

This indicates that the privately optimal amount of security effort $\mathrm{S}^{*}$ provided by individual members of the clan decreases with clan size. This result complements the one derived above, in that $S$ is a good for the collective wealth and a cost for the individual, while conversely, $C$ was a bad for the collective wealth and a good for the individual. The impact of an increase in clan size on the optimized values $\mathrm{S}^{*}$ and $\mathrm{C}^{*}$ thus proceeds in opposite direction, but the rationale rests on similar grounds. An individual member of the clan bears the direct cost $S$ by contributing to the security of his clan, while capturing only a share $1 / \mathrm{N}$ of the benefit derived from increased security. Put differently, individual efforts towards security create a positive externality on the collective wealth of the group which is not fully internalized by the individual agent. Thus, individual efforts will be suboptimal. The share of individual benefit decreases with $N$ (i.e., an increasingly smaller share of the external benefits of $S$ are captured by the individual member), and thus the optimizing level of $S^{*}$ is shown to decline with clan size.

Given these findings, one can study the envelope of the objective function to determine how optimized utility varies with clan size. Substituting the optimizing values $\mathrm{S}^{*}$ and $\mathrm{C}^{*}$ into the original utility function, we can rewrite

$$
\mathrm{U}^{*}=\mathrm{u}\left(\mathrm{N}^{-1}\left[\mathrm{~K}+\mathrm{w}\left(\mathrm{S}^{*}\right)-\mathrm{C}^{*}\right], \mathrm{S}^{*}, \mathrm{C}^{*}\right),
$$

and study

$$
\partial \mathrm{U}^{*} / \partial \mathrm{N}=-\mathrm{N}^{-2} \mathrm{U}_{\mathrm{Y}} \mathrm{W}<0 .
$$

This result indicates that the optimized level of utility $\mathrm{U}^{*}$ decreases with clan size. Both the free riding problem in the provision of $S$, and the common pool 
problem in the choice of $\mathrm{C}$, are exacerbated by an increase in clan size $\mathrm{N}$. The envelope unambiguously reflects these conditions, demonstrating that there are diminishing returns to group size in such early communities. It is immediately evident that also the wealth of the group $\mathrm{W}$ decreases when group size increases, precisely due to the increase in crime and the reduction in security.

These results refer to the individual incentives to provide security and reduce crime and need to be balanced with the obvious economies of scale from group size in defense and production. This suggests that when the economies in production and defense lead to an increased group size, the costs associated with a regime of communal liability will likewise push for a change in the liability regime and a move towards individual responsibility.

These findings are consistent with the observation that the boundaries of the clan for communal responsibility purposes remained quite narrow. Early clans tended to remain relatively small in size, in spite of the forgone economies of scale in external security. External security was obtained through coalitions of clans, but the system of collective ownership and communal responsibility was never extended beyond the closer family (i.e., a group that recognized a common ancestor within the last three, or at most four, generations - Exodus 20:5 and Deuteronomy 5:9). ${ }^{54}$

\subsection{The Effects of an Increase in Group's Wealth on Security and Crime}

Historically, regimes of communal liability are typical of early communities in initial stages of economic development. Communal liability tends to fade away and give rise to systems of individual responsibility as societies evolve. This regularity has been explained by noting that early societies had a limited accumulation of wealth. Limiting liability to the wealth endowments of individual members of the group would have created a truncation of liability under most circumstances. Posner (1980) suggests, for instance, that pecuniary liability of the individual wrongdoer was not a feasible alternative to communal liability or retaliatory sanctions in early legal systems: with their very limited wealth, individual wrongdoers simply could not compensate their victims. It was not until a later stage of economic development that wrongdoers could offer satisfaction to their victims by means of compensation rather than by suffering retaliatory punishment.

\footnotetext{
54 This still characterizes the definition of the family in the Romanistic legal systems, where the finding of a common ancestor within the last three generations serves as the general threshold for establishing a family link.
} 
In the following, we provide another explanation for the rise and subsequent fall of communal liability in early societies. This explanation is also related to economic development, but focuses on the impact of the group's wealth on the individual incentives to provide security and reduce crime. The model interestingly shows that individual incentives are indeed affected by the initial wealth of the group $\mathrm{K}$.

To study the effect of an exogenous change in the group's initial endowment on crime let us first sign $F_{K}$ :

$$
F_{K}=-N^{-2} U_{Y Y}>0 \text {. }
$$

By applying the Implicit Function Theorem on (8) and (16) we can determine how $\mathrm{C}^{*}$ varies with $\mathrm{K}$ :

$$
\partial \mathrm{C}^{*} / \partial \mathrm{K}=-\mathrm{F}_{\mathrm{K}} / \mathrm{F}_{\mathrm{C}}>0
$$

This result suggests that an exogenous increase in the wealth of the group, which might be due to improved technology of production, successful military campaigns, or improved economies of scale due to an increase in group size $\mathrm{N}$, yields an increase in the privately optimal level of crime. This is because, given the decreasing marginal utility of wealth expressed by the negative second derivative $U_{Y Y}$, an increase in wealth actually makes the marginal benefit of reducing crime decrease, while leaving the benefit of committing crime unaltered, hence bolstering crime.

A similar analysis may be conducted on the level of security. Let us first sign $\mathrm{H}_{\mathrm{K}}$ :

$$
H_{K}=N^{-2} U_{Y Y} W_{S}<0
$$

Applying the Implicit Function Theorem on (11) and (18), we can determine the effect on $\mathrm{S}^{*}$ of an increase in $\mathrm{K}$ :

$$
\partial S^{*} / \partial \mathrm{K}=-\mathrm{H}_{\mathrm{K}} / \mathrm{H}_{\mathrm{S}}<0
$$

The effect of $\mathrm{K}$ on $\mathrm{S}^{*}$ runs in an opposite direction if compared to the effect on $\mathrm{C}^{*}$, although they obey the same logic: an increase in $\mathrm{K}$ brings along a decrease in $\mathrm{S}^{*}$. Also in this case, an increase in wealth reduces the marginal productivity of the effort exerted in providing security for the group, while not 
affecting its cost and hence undermines the incentives to provide security.

By studying the envelope of the optimized objective function (14) with respect to $\mathrm{K}$ we obtain:

$$
\partial \mathrm{U}^{*} / \partial \mathrm{K}=\mathrm{N}^{-1} \mathrm{U}_{\mathrm{Y}}>0
$$

While an increase in $\mathrm{N}$ reduces individual utility, an increase in $\mathrm{K}$, although it has the same effects on crime and security, still raises the utility of individuals. An increase in group size dilutes the incentives to provide security and reduce crime as it impoverishes individuals by augmenting the number of members amongst whom the return to their effort is to be divided. On the contrary, an increase in wealth undermines the individual incentives by making each member of the group richer (and hence increases individual utility). The disincentive effect derives from a substitution of private benefits for collective wealth, the marginal utility of which has decreased as a result of the increase in its total value.

\section{Conclusion: From Communal Liability to Individual Responsibility and Public Enforcement}

The liability regime described in Section 2 - a system of absolute and collective responsibility - was an effective instrument for restoring the equilibrium between the parties and preventing blood feuds between opposing clans. ${ }^{55}$ It was not until the 6th century B.C. - approximately nine centuries after the reported words of Moses - that the prophet Ezekiel first spoke about individual judgment for personal sin: "Doth not the son bear the iniquity of the father? When the son hath done that which is lawful and right, and hath kept all my statutes, and hath done them, he shall surely live. ${ }^{\prime \prime 5}$

This passage from the Book of Ezekiel, together with another passage from the Book of Jeremiah, ${ }^{57}$ introduces the principle of individual responsibility that is contained in the Hebraic code. ${ }^{58}$ Such a substantial change in Judaic culture was

\footnotetext{
${ }^{55}$ See Hobhouse (1915), at 144.

${ }^{56}$ Ezekiel 18:19. Similarly, in Ezekiel 18:20: "The soul that sinneth, it shall die. The son shall not bear the iniquity of the father, neither shall the father bear the iniquity of the son; the righteousness of the righteous shall be upon him, and the wickedness of the wicked shall be upon him." Further explanation is given in Ezekiel 18:32: AFor I have no pleasure in the death of him that dieth, saith the Lord God; wherefore, turn yourselves, and live.@

${ }^{57}$ Jeremiah 31:29-30: "In those days they shall say no more, The Fathers have eaten a sour grape, and the children's teeth are set on edge. But every one shall die for his own iniquity; every man that eateth the sour grape, his teeth shall be set on edge."

${ }^{58}$ See Tunc (1974), at 34.
} 
part of the ethical revolution introduced by the later prophets, where the collective guilt referred to in the earlier sources was no longer the basis of the communal responsibility for wrongs. ${ }^{59}$ An individual's sin did not place any blame on the clan or the class to which the wrongdoer belonged, and the diligent clan member was no longer guilty for the wrongs committed by the wrongdoer of his community. ${ }^{60}$

The use of objective criteria of liability outlived the fall of communal liability. The need to provide effective and prompt satisfaction to the victim still required that the punishment be inflicted independently from proof of intent or subjective fault on the part of the offender. Any focus upon subjective considerations would have been an obstacle to a quick and uncontroversial resolution of the dispute. ${ }^{61}$ The establishment of norms for the acceptance of responsibility even in the absence of subjective fault thus reflected both the societal needs of the times and the divine nature of ancient laws, which looked at wrongful actions as breaches of religious rules for which the individual was responsible, regardless of individual blame.

The subsequent detachment of civil remedies from punitive elements was markedly among the slowest processes of legal evolution, ${ }^{62}$ and it was certainly not reached all at once. ${ }^{63}$ This phase is associated with the gradual increase of the

${ }^{59}$ It should be observed that the collective responsibility of the wrongdoer's clan, though an archaic notion, still persists in other non-western societies. The study of an anthropologist describes: "From the supreme law of group solidarity it follows that when an individual has injured a member of another group, his own group shields him while the opposing group supports the injured man's claims for compensation or revenge. Thence there may develop blood-feuds and civil wars. The stubbornness with which these are waged varies in different regions." Lowie (1920).

${ }^{60}$ Daube (1947b), at 155 and 156, explains the evolution from communal responsibility to communal merit: "The sinners shall live for the good works of the pious."

${ }^{61}$ In order to maintain social peace, responsibility had to be isolated from any analysis of the offender's fault, since any such analysis would not have guaranteed immediate satisfaction of the victim's innate desire for vengeance at this early stage of human civilization. It was probably as a corollary to this concept of liability that if a person suffering an injury showed no sign of indignation or resentment at the time of the accident, he was considered to forgive the tortfeasor and to forego his right to compensation. Later Roman law retains signs of the older tradition. Still, in Justinian's Institutes, we read I. 4.4.12: "Haec actio dissimulatione aboletur: et ideo, si quis iniuriam dereliquerit, hoc est statim passus ad animum suum non revocaverit, postea ex paenitentia remissam iniuriam non poterit recolere." For further commentary on the point, see Hunter (1897).

${ }^{62}$ Early Christian doctrine expressly embraced the notion of vindicatio. See, for example, Granfield (1988): "Punishment brings a jarring note to the ideal harmony that is political friendship. Luther, however, described it as 'the strange work of love' a reference that makes Aquinas's term, 'the virtue of vengeance', sound less paradoxical. Perhaps we have seen too much of organized sadism to feel easy about ever calling vengeance virtuous. Actually, the vindicatio that Aquinas praised did not have the pejorative connotations of revenge or vindictiveness that it may have today. The word refers to punishment for a wrong done, even when its purpose is rehabilitative and medicinal. In the Middle Ages, vindicatio was a virtue concerned with the moderate use of authorized coercion, with the proper function of punishment. The virtue stands revealed when we remove the dark vices related to it, "one by way of excess, namely the sin of cruelty or brutality, which exceeds the measure in punishing; while the other is a vice by way of deficiency and consists in being remiss in punishing" (quoting Thomas Aquinas, Summa Theologiae, II-II, q. 108, a. 2, ad 3).

${ }^{63}$ Malone (1970), at 8. More generally, on the Anglo-Saxon evolution, see Pollock and Maitland (1895), at 471-472; and Holmes (1881), at 12. 
state's role in pursuing punishment. The victim is entitled to compensation, and the infliction of punishment becomes part of the state's prerogatives. Increased importance is given to moral justifications and excuses, leading to the gradual inclusion of fault as a prerequisite of liability.

In this paper, we have considered the historical evolution from communal liability to individual responsibility, suggesting that the rise and fall of communal liability was potentially driven by changes in the structure of society. Groups naturally tended to grow larger and wealthier, obtaining economies of scale in defense and production but also exacerbating common pool problems within the group. These problems were contained by two factors. First, members of the clan were originally considered to be the property of their chief and all decisions relating to clan security were made directly by the chief. ${ }^{64}$ The concentration of the control and residual interest in the hands of the clan chief helped control the opportunistic behavior of clan members.

Second, these societies were characterized by a substantial lack of privacy and this facilitated the opportunities for cross-monitoring members within the group. Posner (1980) considers the function of privacy, or lack thereof, in a system characterized by communal responsibility and collective ownership. He maintains that the characteristics of strict and communal liability for injuries, and collective guilt, fundamentally derive from the high information costs of ancient society. A way of limiting these costs is by maintaining crowded living conditions that deny privacy, thereby increasing the production of information (but at the same time reducing the production of some socially useful information by failing to assign a property right in such information). Because of the limited extent of personal privacy, detection of crimes is high and so is the probability of punishment. This in turn serves to keep the required level of sanctions low and to moderate the lack of individual incentives to contribute to the common good.

${ }^{64}$ It has been observed that inflicting punishment upon a member of the wrongdoer's clan is "a natural thing in a system under which the people of a King, or a man's wife or his children, are, up to a point, his property, not unlike slaves. To attack that property is to attack the King, the husband, the father, as much as to attack a herd of cattle or a slave would be to attack the owner." Daube (1947b), at 170-171. 
Our analysis shows that individual incentives are diluted by an increase in group size and wealth. This means that when communities grow bigger and wealthier, besides having more difficulty keeping privacy at a very low level, individuals tend to loosen their cooperation in the public good, both in terms of crime reduction and of provision of security for the group. We maintain that this might explain the historical evolution towards systems of individual responsibility and in general towards the limitation of the size of the group that was to be held collectively responsible for the wrongs of its members.

\section{References}

Anderson, N.D. 1951. Homicide in Islamic Law. Bulletin of the School of Oriental and African Studies, 823.

Blau, J. 1916. Lex Talionis. Yearbook of the Central Conference of American Rabbis, 26, 1 .

Daube, D. 1947a. Lex Talionis, in David Daube, Studies in Biblical Law. Cambridge, England: University Press.

Daube, D. 1947b. Communal Responsibility, in David Daube, Studies in Biblical Law. Cambridge, England: University Press.

De Coulanges, F. 1915. Religious Origin of Ancient Law, in Albert Kocourek and John H. Wigmore (eds.), Primitive and Ancient Legal Institutions, 107. Boston: Little, Brown \& Co.

Diamond, A. S. 1971. Primitive Law: Past and Present. London: Methuen.

Driver, G. R. and Miles, J C. 1952. The Babylonian Laws. Oxford: Clarendon Press.

Faris, E, 1915. The Origin of Punishment, in Albert Kocourek and John H. Wigmore (eds.), Primitive and Ancient Legal Institutions, 151. Boston: Little, Brown \& Co.

Gaudemet, J. 2002. Institutions de I'Antiquité, $4^{\text {th }}$ ed.. Paris: Montchrestien.

Granfield, D. 1988. The Inner Experience of Law, a Jurisprudence of Subjectivity. Washington, D.C.: Catholic University of America Press.

Grotius, H. 1625. De Iure Belli ac Pacis 2.20.5 (W. Whewell ed. 1853). London: Cambridge University Press.

Hobhouse, L.T. 1915. Development of Justice, in Albert Kocourek and John H. 
Wigmore (eds.), Primitive and Ancient Legal Institutions, 141. Boston: Little, Brown \& Co.

Hoebel, E.A. 1954. The Law of Primitive Man; A Study in Comparative Legal Dynamic. Cambridge, MA: Harvard University Press.

Holmes, O. W. Jr., 1881. The Common Law. Boston: Little, Brown \& Co.

Hunter, W. A. 1897. Roman Law (3rd ed). London: Sweet \& Maxwell.

L'Hour, J. 1963. Une Législation Criminelle dans le Deutérunome. Biblica, XLIV, 1.

Lowie, R. H. 1920. Primitive Society. New York: Boni \& Liveright.

Maine, H. S. 1861. Ancient Law. Its Connection with the Early History of Society and Its Relation to Modern Ideas. London: John Murray.

Maine, H. S. 1883. Early Law and Custom. New York: Henry Holt.

Malone, W. S. 1970. Ruminations on the Role of Fault in the History of Torts. Louisiana Law Review, 31, 1.

Mueller, D. H. 1904. Über Die Gesetze Hammurabis. Vienna: Holder Publishing.

Parisi, F. 1992. Liability for Negligence and Judicial Discretion, $2^{\text {nd }}$ ed. (Berkeley, California).

Parisi, F. 1997. Liability Without Fault and Communal Responsibility in Ancient Legal Systems, GMU LaW \& ECONOMICs Working PAPER SeRIES, \#97-08.

Parisi, F. 2001. The Genesis of Liability in Ancient Law, American Law and Economics Review, 3, 82-124.

Pollock, F. and Maitland, F. 1895. The History of English Law. Birmingham, U.K.: Legal Classics Library.

Posner, R. A. 1980. A Theory of Primitive Society, With Special Reference to Law, Journal of Law and Economics, 23, 1.

Posner, R. A. 1981. The Economics of Justice. Cambridge, Massachusetts: Harvard University Press.

Posner, R. A. 1988. Law and Literature: A Misunderstood Relation. Cambridge, Massachusetts: Harvard University Press.

Powell, J.W. 1915. Kinship, in Albert Kocourek and John H. Wigmore (eds.), Primitive and Ancient Legal Institutions, 181. Boston: Little, Brown \& Co.

Roth, M. T. (transl.). 1995. Law Collections from Mesopotamia and Asia Minor. 
Atlanta, Georgia: Scholars Press.

Stein, P. 1984. Legal Institutions: The Development of Dispute Settlement. London: Butterworths.

Stein, P. 1999. Roman Law in European History. Cambridge, UK: Cambridge University Press.

Strachan-Davinson, J.L. 1912. Problems of the Roman Criminal Law. Oxford, U.K.: Clarendon Press.

Sulzberger, M. 1915. The Ancient Hebrew Law of Homicide. Philadelphia: Julius H. Greenstone.

Tunc, A. 1974. "Introduction", in Tunc, A. (ed.), Torts, International Encyclopedia of Comparative Law. Tübingen: Mohr.

Williams, G. L. 1951. The Aims of the Law of Torts. Current Legal Problems, 4, 138. 